\title{
RESEARCH PAPER \\ A simple method for estimating suitable territory for bioenergy species in Chile
}

\author{
Luis Morales-Salinas ${ }^{1}$, Edmundo Acevedo 1 , Giorgio Castellaro ${ }^{1}$, Luis \\ Román-Osorio ${ }^{2}$, Jael Morales-Inostroza ${ }^{1}$ and Máximo F. Alonso ${ }^{1}$ \\ 'Facultad de Ciencias Agronómicas, Universidad de Chile. Casilla 1004, Santiago, Chile. \\ ${ }^{2}$ Instituto Nacional de Investigaciones Agropecuarias, Ururi. Magallanes 1865, Arica, Chile.
}

\begin{abstract}
L. Morales-Salinas, E. Acevedo, G. Castellaro, L. Román-Osorio, J. Morales-Inostroza, and M.F. Alonso. 2015. A simple method for estimating suitable territory for bioenergy species in Chile. Cien. Inv. Agr. 42(2): 227-242. In the past 20 years, different areas of research concerning native and exotic species, herbaceous crops and forest plantations have been oriented toward satisfying domestic, industrial and transportation energy requirements. Because bioenergy species constitute an important resource, it would be strategic for a country to have a method for identifying areas suitable for their cultivation to properly incorporate the establishment of energy crops into land use planning. In this study, we sought to define the suitable territories for 16 bioenergy species and their energy potential based on their soil and climate requirements in Central and Southern Chile. We used an adapted version of the FAO EcoCrop database implemented through DIVA-GIS software to predict the crop suitability of different geographical areas, and our results indicate that this method is a simple way to identify land suitable for the establishment of bioenergy species, which is information that can be used in land use planning. Furthermore, spatially explicit regression and ordinary kriging proved to be satisfactory tools for interpolating data from weather station networks through the generation of continuous climatic information grids. Land suitability is presented at a scale of $1: 1,000,000$ in a continuous digital format expressed in probabilistic terms.
\end{abstract}

Key words: Bioenergy species, EcoCrop, ecological niche model, land suitability.

\section{Introduction}

Biomass is a renewable source of energy, and its use is of particular interest because it can reduce greenhouse gas emissions, waste volume

Received July 1, 2014. Accepted April 3, 2015. Corresponding author: 1morales@renare.uchile.cl in landfills and dependence on non-renewable energy sources (Rudnick et al., 2011).

Biomass has high energy potential in Chile, and the primary sources are the residues from the management and utilization of native and commercial forests (ProChile, 2009). According to a study of the biomass market in Chile (UACH, 
2013), there are 2 million hectares available for the establishment of energy crops nationwide, which would reduce the country's dependence on imported energy and improve the condition of soils degraded as a result of human action (FAO, 2008).

Territorial suitability has a direct impact on crop productivity (Parthasarthy et al., 2007), and climatic variables are the most important factors determining the geographic distribution of a species, although soil variables are important as well. Currently, there is a wide variety of available ecological niche models (Grinnell 1917, 1924; Leibold, 1995; Chase and Leibold, 2003), such as GARP (Stockwell and Peters, 1999), Maxent (Phillips, 2006), BIOCLIM (Busby, 1991), and EcoCrop (FAO, 2000) among others. All can be used to identify areas with optimal climatic conditions for growing crops (Parthasarthy et al., 2007; Pliscoff and Fuentes, 2011), but due its simplicity, EcoCrop has comparative advantages for modeling the potential geographic distribution of a species (Ramirez-Villegas et al., 2013).

EcoCrop calculates a suitability index for the growth of a species based on climatic parameters (i.e., absolute and optimal temperatures and precipitation), and the predictive model is implemented in DIVA-GIS software (Hijmans et al., 2002). However, although it is frequently used, the EcoCrop model does not account for soil properties when predicting land suitability, and this could be restrictive when modeling crop potential (RamirezVillegas et al., 2013).

This study proposes a simple method for the determination of land suitability for 16 energy species in the Central and Southern zones of Chile. The method is an adaptation of the EcoCrop model that predicts land suitability based on both soil and climate species requirements.

\section{Materials and methods}

\section{Study area and selected species}

From north to south, the study area covered eight regions within the current administrative divisions in Chile: Valparaíso (Valparaíso), Metropolitana (Santiago), O’Higgins (Rancagua), Maule (Talca), Bío-Bío (Concepción), Araucanía (Temuco), Los Ríos (Valdivia) and Los Lagos (Puerto Montt) (Figure 1).

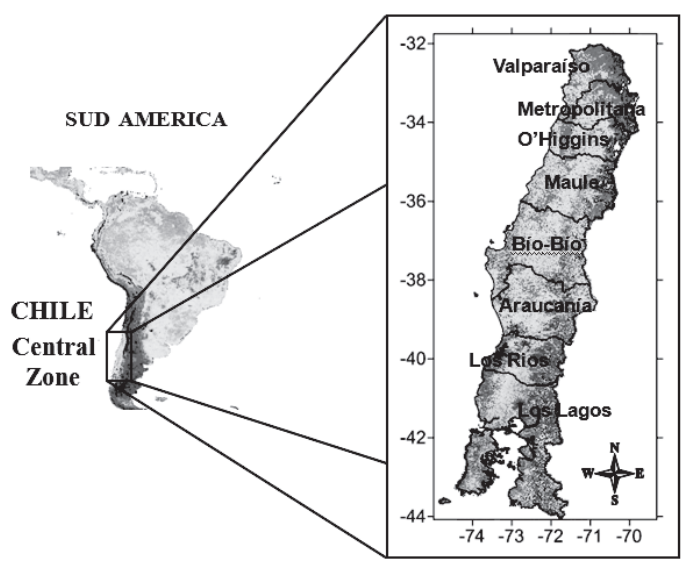

Figure 1. The study area in Central and South-Central Chile.

The following bioenergy species were assessed: Acacia melanoxylon, Acacia mearnsii, Acacia dealbata, Acacia saligna, Eucalyptus camaldulensis, Eucalyptus globulus, Eucalyptus nitens, Opuntia ficus-indica, Paulownia spp., Populus deltoides, Populus spp, Robinia pseudoacacia, Salix viminalis, Arundo donax, Panicum virgatum and Miscanthus $x$ giganteus. These species were selected because of their high performance in different countries, the quality of their biomass for energy production purposes and their high yield potential in Central and Southern Chile (Alonso et al., 2010).

\section{Climatic information}

The climatic data came from four sources: Climatología de Chile (PNUD-Gobierno de Chile, 1964), 
Atlas Agroclimático de Chile (Novoa et al., 1989), Dirección General de Aguas (DGA) and Dirección Meteorológica de Chile (DMC). Temperature and precipitation data were collected from 1,239 weather stations located in the above-mentioned regions, but only stations with a minimum of 10 years of continuous data were considered. Thus, data from a total of 625 weather stations with a minimum of 11 years and a maximum of 140 years of monthly averaged information were used and compared to similar studies (Novoa et al., 1989; Santibáñez and Uribe, 1990, 1993a and 1993b). Because data from different sources were indexed under different cartographic projections and time zones, they were standardized under the same index system (WGS84 spherical datum).

\section{Digital elevation model}

A digital elevation model (DEM) corresponds to a data matrix with a spatial distribution of altitudes (Felicísimo, 1994). In this study, the free distribution DEM model from the Shuttle Radar Topography Mission (SRTM) was used in the construction of the topoclimatic model, and the data corresponded to SRTM-4 with a 90-m pixel, which is a scale of approximately 1:100,000 (Farr et al., 2007). The slope and aspect variables were calculated from the DEM, and the distance to the coast was estimated by calculating the linear distance from the coast to one of the pixels in the DEM matrix.

\section{Topoclimatic modeling}

Minimum, average and maximum temperatures for January and July and average annual precipitation were used in a geographically weighted multiple regression model (Novoa et al., 1989; Santibáñez and Uribe, 1990, 1993a and 1993b) with latitude (LAT), longitude (LON) and altitude (ALT) as the predictor variables (Fotheringham et al., 2002).
The climatic variation over the study area was represented by physiographic and land use factors and determined by a topoclimatic analysis (Morales et al., 2006), which quantitatively modeled the climate using a combination of land surface parameters (Okolowicz, 1969; Kaminski and Radosz, 2002).

To estimate the spatial variability of the climatic data, global regressions were run with one spatial variable. The coefficients of the resulting equation could have had significant spatial variation (Morales et al., 2007, 2010). Thus, spatially explicit equations describing the changes in climatic variables were calculated using weighted least squares; the weight was dependent on the distance between each point and the rest of the observations (Berry and Feldman, 1985; Fotheringham et al., 2002). The geographically weighted regression (GWR; Brunsdon et al., 1996) was used to find the spatial variability in the estimated parameters through a multiple linear regression that incorporates the geographical coordinates of the observations into its equation.

In summary, the goal was to adjust the same number of regressions as the number of observations in the space considered in the analysis based on the hypothesis that closer observations have greater weights in the regression, which is simulated by a function that decays with distance. The climatic variables were modeled by Equation [1]:

$\mathrm{y}_{\mathrm{i}}=\mathrm{a}_{0}\left(\mathrm{u}_{\mathrm{i}}, \mathrm{v}_{\mathrm{i}}\right)+\sum_{\mathrm{k}} \mathrm{a}_{\mathrm{k}}\left(\mathrm{u}_{\mathrm{i}}, \mathrm{v}_{\mathrm{i}}\right) \mathrm{x}_{\mathrm{ik}}+\varepsilon_{\mathrm{i}}$ [Eq.1] where $\left(u_{i}, v_{i}\right)$ indicates the coordinates of the $i^{\text {th }}$ point in the space; $y_{i}$ is the value of the dependent variable; $x_{i k}$ is an independent descriptive variable at point $\mathrm{i} ; \mathrm{a}_{\mathrm{k}}\left(\mathrm{u}_{\mathrm{i}}, \mathrm{v}_{\mathrm{i}}\right)$ is a regression parameter for the independent variable, and $\varepsilon_{\mathrm{i}}$ is the error at point $i$. The coefficients, $a_{k}\left(u_{i}, v_{i}\right)$, were determined as follows:

$a_{k}\left(u_{i}, v_{i}\right)=\left[X^{T} \cdot W\left(u_{i}, v_{i}\right) \cdot X\right]^{-1} \cdot X^{T} \cdot W\left(u_{i}, v_{i}\right) \cdot Y$ [Eq.2] 
where the independent observations or descriptive variables are in the $\mathrm{X}$ matrix, and the dependent variables are in the $\mathrm{Y}$ matrix. $\mathrm{W}_{\mathrm{i}}$ is a diagonal matrix of $(N, N)$ order in which the elements of the diagonal are the weights, $\mathrm{w}_{\mathrm{ij}}$, which are a function of the focal observation and the rest of the observations (Fotheringham et al., 1997, 2000 and 2002). They are calculated by the following equation:

$$
\mathrm{W}\left(\mathrm{u}_{\mathrm{i}}, \mathrm{v}_{\mathrm{i}}\right)=\mathrm{e}^{-\alpha \cdot \mathrm{d}_{\mathrm{ij}}^{2}}
$$

where $\alpha$ is a parameter expressing the decreasing distance between two points in space, and dij is the distance between points $i$ and $j$. From a practical point of view, a point that is more distant from i will have less statistical influence on the final numeric relationship (Morales et al., 2007). It is noteworthy that the descriptive variables, $\mathrm{x}_{\mathrm{ik}}$, can be derived from interactions among or powers of the fundamental variables (Morales et al., 2006).

The statistical model of the spatial distribution of the climatic variables with GWR [Equation 1] was formulated using a computer code developed with the statistical software R ( R Development Core Team, 2009). The digital mapping method based on the topoclimatic model was carried out using Idrisi $32 \circledR$ software tools (Clark University, Worcester, MA, USA); digital charts of latitude, longitude and altitude were used as independent variables in the multiple regressions defined in Equation [1]. Under this procedure, a value for the climatic variables was obtained for each pixel, which generated a digital map composed of seven image files (maximum, minimum and average temperature for January and July; annual average precipitation). The resulting climatic variable matrices have the same dimensions as the matrices for the independent variables, i.e., the same number of rows and columns as for latitude, longitude and altitude.

\section{Soil information}

To create digital charts of the soil variables, we collected and digitized soil data from basic sources of soil information (CIREN, 1996, 1997, 1999a, 1999b, 2001). The soil variables (properties) associated with each soil series were both (1) qualitative, which included the soil order and taxonomic classification of the soil series (USDANRCS, 1999), and (2) quantitative, which included the depth of each soil layer (SD) as well as its textural class, particle distribution, field capacity, wilting point, bulk density, $\mathrm{pH}$, organic carbon and organic matter contents. Using the depth of each soil layer as the weighting factor, weighted averages of each of the soil variables representing the soil series profile were calculated.

Some of the soil series in the study area were obtained from previous reports and studies (CIREN, 1996, 1997, 1999a, 1999b, 2001), so the quantitative information for the modal profile was incomplete for these variables. The GWR algorithm was used to estimate depth and soil $\mathrm{pH}$ according to descriptive variables or covariables, which were the altitude and normalized difference vegetation index (NDVI) value at each point in the territory from MODIS images (Saini, 1966; Rawls et al., 1982; Saxton et al., 1986; Heuscher et al., 2005). The model used to estimate the missing data is proposed in Equations 1 to 3. As for the climatic variables, the regression coefficients in Equation 1 were calculated using the multiple linear GWR method, in which the independent variables were altitude and the NDVI-MODIS value (Fotheringham et al., 1997, 2000, 2002). Due its widespread use and good results, ordinary kriging was used to estimate the spatial variability of the coefficients of the equation used to estimate soil depth and $\mathrm{pH}$ (Ojeda et al., 2011; Martinez-Cob, 1996; MirandaSalas and Condal, 2003; Vicente-Serrano et al., 2003). The equation was applied using interpolated coefficients determined by SIG Idrisi 32® software on each polygon from the soil vectorial files to estimate the variables in those series for which there were no values. The polygon vectorial files were rasterized, and the resulting matrices had the same dimensions as the matrices of the independent variables and thus the same number of rows and columns as altitude and NDVI. 
Land suitability and plant species adaptability

According to the ecological characteristics of the different species, A. melanoxylon is found between regions VII and $\mathrm{X}$ in the Central Valley below an altitude of $500 \mathrm{~m}$ in red and yellow podzolic or alluvial soils (Hebert and Baurele, 1995). A. mearnsii is found between regions $\mathrm{V}$ and $\mathrm{X}$ in low coastal zones and foothills from sea level to $900 \mathrm{~m}$ (INFOR, 2000a). A. dealbata is located in warm to cold sub-humid zones; it is found from high steppes to deep valleys along streams and rivers (INFOR, 2000a). A. saligna is distributed between regions III and VII where it tolerates superficial saline and alkaline soils and grows in zones of irregular and limited precipitation between 100 to $250 \mathrm{~mm}$ year ${ }^{-1}$ (INFOR, 2001). E. camaldulensis grows in zones with an annual precipitation of $250 \mathrm{~mm}$ year ${ }^{-1}$ from sea level to $600 \mathrm{~m}$ in altitude, and it tolerates poor and degraded soils of low to moderate fertility (INFOR, 2000b). In Chile, there are numerous Eucalyptus species including E. globulus, E. nitens and E. camaldulensis. E. globulus grows in a precipitation range from 200 to $1,250 \mathrm{~mm}$ year $^{-1} ; E$. nitens grows in a range of 750 to 1,350 $\mathrm{mm}_{\text {year }}{ }^{-1}$ and E. camaldulensis between 600 to $1,100 \mathrm{~mm}$ year $^{-1}$. All of these species grow in thin, moderate and deep and silty to clay loamy soils with light to heavy textures (INFOR, 2005). $O$. ficus-indica is located at altitudes between 800 to $1,800 \mathrm{~m}$ in clay loamy soils with a $\mathrm{pH}$ value between 6.5 to 8.5 and precipitation of 150 to $1,800 \mathrm{~mm}$ year ${ }^{-1}$. It tolerates drought and requires a mean annual temperature between 16 to 28 ${ }^{\circ} \mathrm{C}$ (Gerencia Regional Agraria de La Libertad, 2009). Populus sp. are found between 300 to $3,000 \mathrm{~m}$ and require temperatures ranging between 14 and $30^{\circ} \mathrm{C}$, precipitation between 1,200 to $2,500 \mathrm{~mm}_{\text {year }}{ }^{-1}$ and light to moderate soil textures (Cazanga et al., 2010). R. pseudoacacia naturally grows in regions with a Mediterranean climate including annual precipitation between 500 to $1,500 \mathrm{~mm}$ and a mean annual temperature between 10 and $18{ }^{\circ} \mathrm{C}$. It tolerates all types of soils with the exception of those that are extremely dry or compacted (INFOR, 1999). A. donax, Panicum virgatum and Miscanthus $x$ giganteus are perennial rhizomatous grasses, and they all grow on almost any soil type from light to moist and compact with a $\mathrm{pH}$ from 5 to 8.7. A. donax tolerates salinity and requires a minimum temperature of $9{ }^{\circ} \mathrm{C}$; $P$. virgatum requires a minimum temperature of $13{ }^{\circ} \mathrm{C}$, and Miscanthus $x$ giganteus requires deep soils and a minimum temperature of $6^{\circ} \mathrm{C}$ (El Bassam, 2010).

The adaptability of a species was expressed as a relative score (0-1), where 0 indicates null adaptability and 1 indicates an optimum fit. This score was calculated using five meteorological variables (annual rainfall, maximum and minimum temperature in the warmest (January) and coldest (July) months) and two soil variables (depth and $\mathrm{pH}$ ). To generate the scores, a response or performance function to each of these variables was calculated for all of the species based on their soil and climate requirements. These values were obtained from the EcoCrop database (FAO, 1997, 2000), and the adaptability score for annual rainfall, temperature and soil $\mathrm{pH}$ was defined by the function shown in Figure 2. The performance function for a species can be described by a parameterized function with four coefficients specific to each species (Table 1): minimum critical value $\left(\mathrm{V}_{\text {min }}\right)$, minimum optimal value $\left(\operatorname{Vop}_{\min }\right)$, maximum optimal value $\left(\operatorname{Vop}_{\max }\right)$ and maximum critical value $\left(\mathrm{V}_{\text {max }}\right)$. The species performance function (F) was calculated with the following equation:

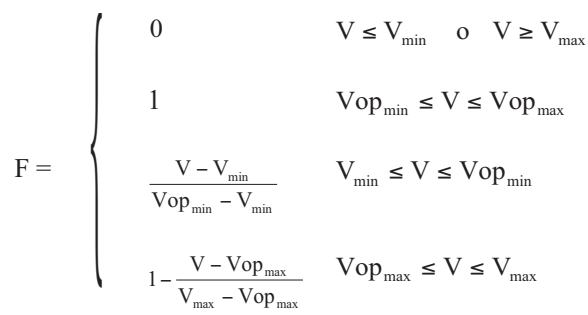

The performance function (F) for soil depth (SD) is described by two coefficients: $\mathrm{V}_{\text {min }}$ and Vop ${ }_{\text {min }}$, which are specific to each species (Table 1). The performance function was calculated according to the following equation: 


$$
\mathrm{F}= \begin{cases}0 & \mathrm{~V} \leq \mathrm{V}_{\min } \\ 1 & \mathrm{~V} \geq \mathrm{Vop}_{\min } \quad[\text { Eq.5] } \\ \frac{\mathrm{V}-\mathrm{V}_{\min }}{\mathrm{Vop}_{\min }-\mathrm{V}_{\min }} & \mathrm{V}_{\min } \leq \mathrm{V} \leq \mathrm{Vop}_{\min }\end{cases}
$$

After calculating the performance function for precipitation $\left(\mathrm{F}_{\mathrm{pp}}\right)$ and temperature $\left(\mathrm{F}_{\mathrm{t}}\right)$ and the soil variables $\mathrm{pH}\left(\mathrm{F}_{\mathrm{pH}}\right)$ and depth $\left(\mathrm{F}_{\mathrm{depth}}\right)$, an index of overall adaptability (IA) was obtained from the weighted linear sum of all of the adaptability functions (Equations 6 and 7):

$$
\begin{aligned}
& \mathrm{IA}=\sum_{\mathrm{i}=1}^{\mathrm{N}} \mathrm{W}_{\mathrm{i}} \cdot \mathrm{F}_{\mathrm{i}} \\
& \sum_{\mathrm{i}=1}^{\mathrm{N}} \mathrm{W}_{\mathrm{i}}=1
\end{aligned}
$$

where $\mathrm{W}_{\mathrm{i}}$ represents the specific weight assigned to each variable $\mathrm{F}_{\mathrm{i}}$. The weights for annual rainfall, temperature, $\mathrm{pH}$ and soil depth were defined as $0.35,0.35,0.10$ and 0.20 , respectively (Equation 8 ) based on expert judgment and previous studies (Cazanga et al., 2010).

$\mathrm{IA}=0.35 \cdot \mathrm{F}_{\mathrm{pp}}+0.35 \cdot \mathrm{F}_{\mathrm{t}}+0.1 \cdot \mathrm{F}_{\mathrm{pH}}+0.2 \cdot \mathrm{F}_{\mathrm{depth}}$

The variables included in the index (IA) were processed with Idrisi ${ }^{\circledR} 32$ software to produce digital charts of the adaptability of each species at a scale of 1:250,000 in the WGS84 and latitude and longitude projection in degrees. The species adaptability results should be interpreted based on the maximum productivity without climatic restrictions (FAO, 1997). From the literature and the IA values, it is possible to classify suitability into the following categories: very suitable $(>80 \%)$, suitable (60-80\%), moderately suitable (40-60\%), marginally suitable (20-40\%) and unsuitable $(<20)$ and to assign each category the ranks of 5, 4, 3, 2, or 1, respectively (Sridhar et al., 2014; Fand et al., 2014; Mendas and Delali, 2012; Parra-Quijano et al., 2012; Sonder et al., 2010; Geerts et al., 2006; Utpala et al., 2006).

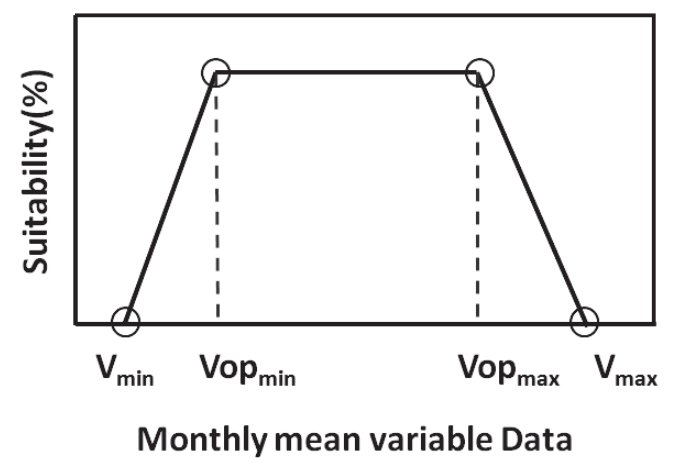

Figure 2. Species performance functions based on the independent soil and climate variables.

Statistical analysis

The statistical analysis compared the simulated and observed results. For the agroclimatic variables, the comparisons were made at a monthly average level, but a single value was compared at a territorial level for the soil variables. The BIAS, MBE (mean bias error), MABE (mean absolute bias error), RMSE (root mean square error) statistics were calculated. A simple regression analysis was performed to determine the coefficient of determination $\left(\mathrm{r}^{2}\right)$, which is widely used to evaluate the goodness of fit between calculated and observed values, and the index of agreement, or Nash-Sutcliffe model efficiency (E), was also determined (Yorukoglu and Celik, 2006; Almorox et al., 2005; Legates and McCabe, 1999). Due to its utility in comparisons of two or more statistical models that use the same dependent variable, the Akaike Information Criteria (AIC) was applied to evaluate the GWR topoclimatic model (Akaike, 1973; Burnham and Anderson, 2002).

\section{Results}

\section{Topoclimatic modeling}

The values of the spatially modeled annual mean rainfall (AMR), mean temperature in January and July (TM01, TM07), maximum temperature in January and July (TX01, TX07) and minimum 


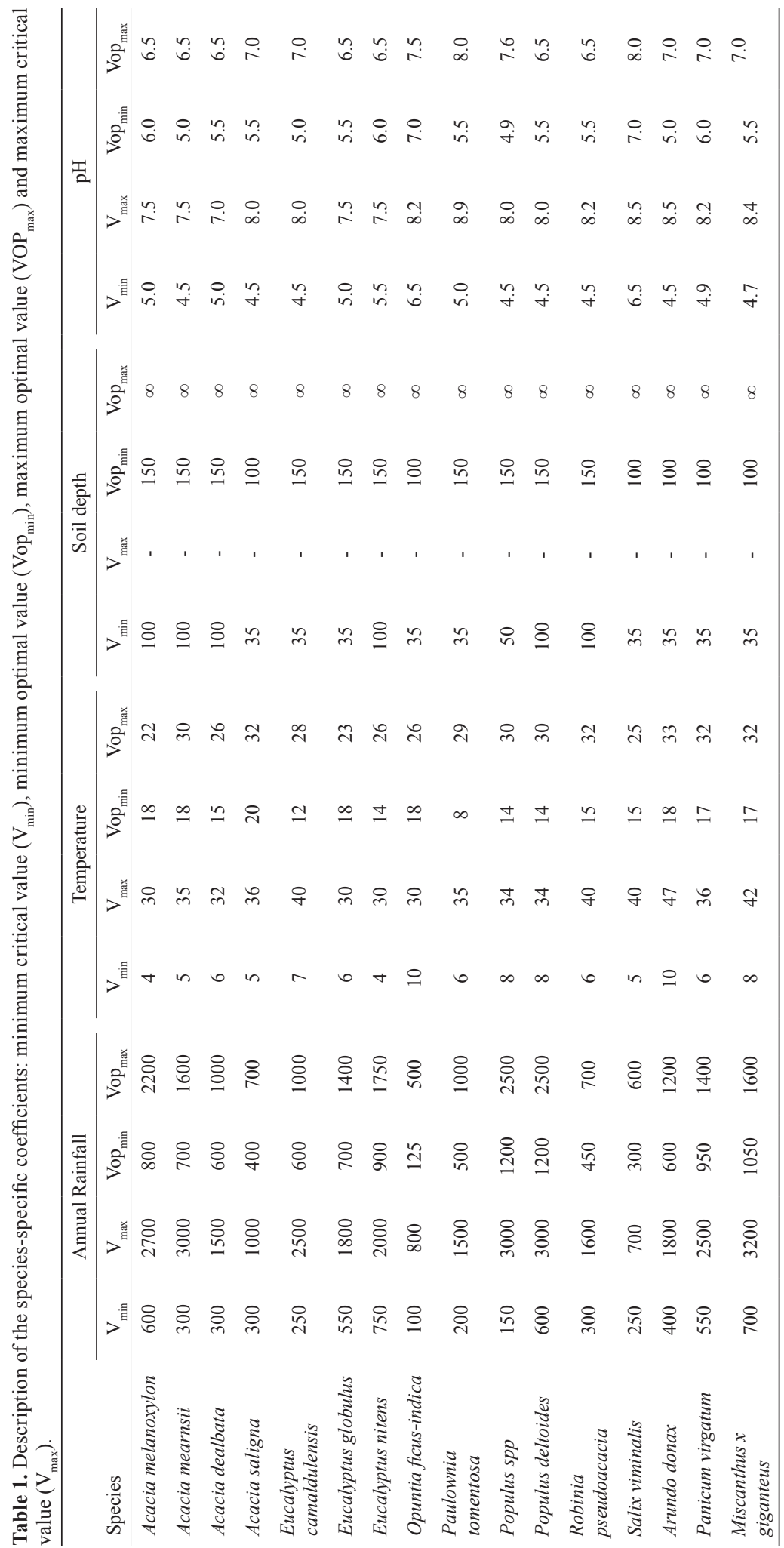


temperature in January and July (TN01, TN07) are presented in Table 2. The root mean square error (RMSE), the efficiency ratio (E), the statistical variance parameters, the regression parameters (adjusted $\mathrm{r}^{2}$ and the significance value, $\mathrm{P}$ ) and the Akaike information criteria (AIC) are also presented in Table 2. The efficiency ratio of the model ranged from 48 to $92 \%$ for the average and maximum temperatures in July, and the adjusted coefficient of determination $\left(\mathrm{r}^{2}\right)$ indicates that the model explains between 67 and $89 \%$ of the variability in each of the climatic variables depending on the altitude. The $\mathrm{P}$ value indicates that the relationships are statistically significant at a $99 \%$ confidence level for each model, and the results show that it is possible to estimate the spatial distribution of each climate variable by altitude. The annual average values were calculated from the average monthly matrices of each of the variables. The spatial distributions of some of the variables modeled by the regression equations are shown in Figure 3(a,b).

Based on the statistical criteria, the results presented in Table 1 are satisfactory and more accurate compared with those from previous studies (Novoa et al., 1989; Santibañez and Uribe, 1992). In Chile, the previously used methods have been based on the interpolation of isolines, which are usually drawn freehand by an expert climatologist, but this method fails when attempting linear interpolations between isolines (Declercq, 1986). Indeed, the results obtained by interpolating between isolines are highly method-dependent and only constitute a trend. Instead, with the methodology used in this work, the maps of the climatic variables are generated by a continuous spatial model in a digital format with the advantage that they can be integrated into a geographic information system (GIS) for easy analysis and incorporation with other databases.

\section{Soil variables}

Soil depth and $\mathrm{pH}$ are shown in Table 3. The calculated ratios illustrate the variability in their spatial distribution, so it was not feasible to use only one equation coefficient for the entire study area. The analyses yielded an E of $71 \%$ in the estimation of soil depth with an RMSE of 14.85, which is equivalent to $5.21 \%$, and an $\mathrm{r}^{2}$ of 0.876 (P $=0.01$ ). Soil $\mathrm{pH}$ had a higher agreement rate of $80 \%$, an RMSE of 0.41 , which is equivalent to $6.44 \%$, and an $\mathrm{r}^{2}$ of $0.81(\mathrm{P}=0.01)$. Figure 3(c, d) shows the results of the estimation of soil depth and $\mathrm{pH}$ in throughout the study area.

\section{Species zoning}

The suitability maps of the studied species are shown in Figure 4; the suitability of the land for each species is indicated by the color bar.

To interpret the results, we used the homogeneous environmental area zones developed by ODEPA, Ministerio de Agricultura (Chile), which correspond to a synthetic description of the Chilean agricultural sector. ODEPA also delivered a complete database with the information collected in the $7^{\text {th }}$ National Agricultural Census (2007). It is not advisable for bioenergy crops to compete for the land used for food crops, so bioenergy species

Table 3. Linear regression coefficients for the estimation of the spatial variation in soil depth (SD) and $\mathrm{pH}$ as a function of altitude and the NDVI coefficient using a GWR model. RMSE: mean quadratic error; E: efficiency index; $\mathrm{r}^{2}$ : determination coefficient and AIC: Akaike criterion.

\begin{tabular}{lccccccccccc}
\hline Variable & \multicolumn{2}{c}{ Intercept } & \multicolumn{2}{c}{ Altitude Coefficient } & \multicolumn{2}{c}{ NDVI Coefficient } & RMSE & $\mathrm{E}$ & $\mathrm{r}^{2}$ & $\mathrm{P}^{1}$ & $\mathrm{AIC}^{2}$ \\
\hline $\mathrm{SD}$ & 92.81659 & \pm 7.585 & -0.00155 & \pm 0.024097 & 0.5005 & \pm 6.93701 & 14.85 & 0.71 & 0.876 & $* *$ & 8977.572 \\
$\mathrm{pH}$ & 5.79069 & \pm 469.42 & 0.09378 & \pm 1.12473 & -5.70803 & \pm 618.2 & 0.413 & 0.80 & 0.810 & $* *$ & 2372.196 \\
\hline
\end{tabular}

1** $\mathrm{P} \leq 0.01$

${ }^{2}$ AIC: Akaike criterion 
Table 2. Linear regression coefficients for the estimation of the spatial variation in the climatic variables under study as a function of altitude using a GWR model. RMSE: mean quadratic error; E: efficiency index; $r^{2}$ : determination coefficient and AIC: Akaike criterion.

\begin{tabular}{cccccccccc}
\hline Variable & \multicolumn{2}{c}{ Intercept } & \multicolumn{2}{c}{ Slope } & RMSE & $\mathrm{E}$ & $\mathrm{r}^{2}$ & $\mathrm{p}^{1}$ & AIC $^{2}$ \\
\hline AMR & 1053.504 & \pm 30.75 & -0.26043 & \pm 0.025716 & 317 & 0.88 & 0.87 & $* *$ & 18165.23 \\
TM01 & 18.265 & \pm 0.247 & -0.00167 & \pm 0.000168 & 1.53 & 0.87 & 0.83 & $* *$ & 1361.25 \\
TM07 & 9.493 & \pm 0.379 & -0.001633 & \pm 0.000258 & 4.3 & 0.48 & 0.76 & $* *$ & 1931.76 \\
TX01 & 25.138 & \pm 0.315 & -0.0014 & \pm 0.000228 & 1.9 & 0.86 & 0.82 & $* *$ & 1648.08 \\
TX07 & 13.518 & \pm 0.316 & 0.000096 & \pm 0.000228 & 1.4 & 0.92 & 0.89 & $* *$ & 1472.10 \\
TN01 & 11.769 & \pm 0.205 & -0.001851 & \pm 0.000147 & 2.0 & 0.71 & 0.70 & $* *$ & 1506.10 \\
TN07 & 5.4035 & \pm 0.214 & -0.00237 & \pm 0.000153 & 2.4 & 0.82 & 0.67 & $* *$ & 1628.17 \\
\hline
\end{tabular}

$1 * * \mathrm{P} \leq 0.01$.

${ }^{2}$ AIC: Akaike Criterion.

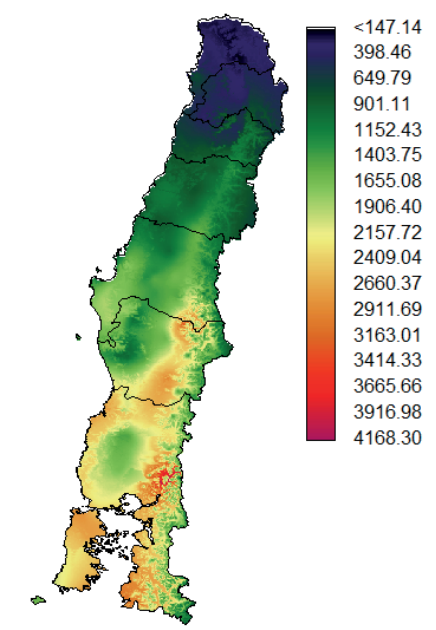

(a)

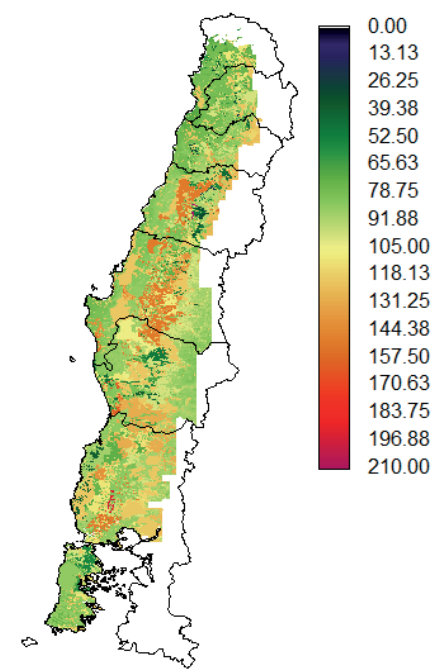

(c)

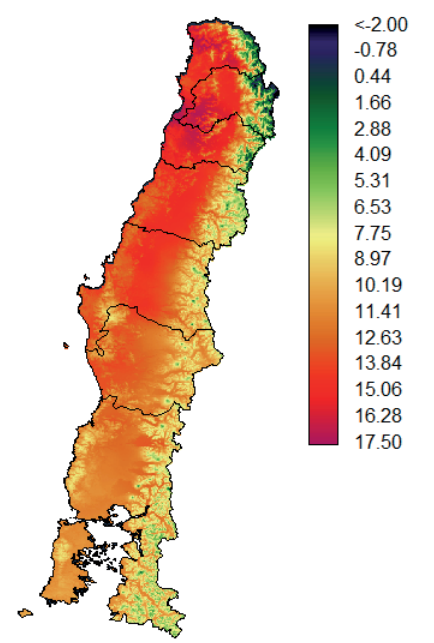

(b)

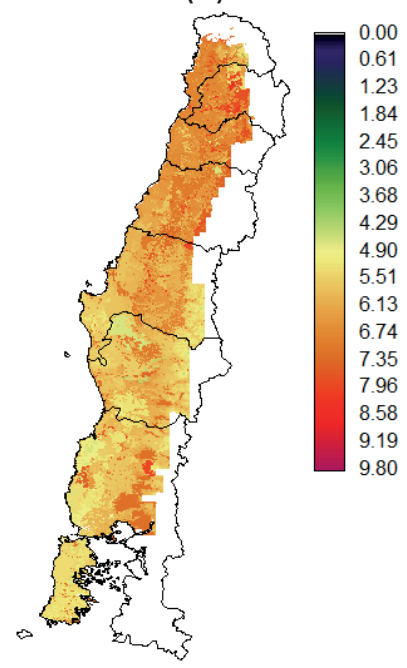

(d)

Figure 3. Spatial distributions of (a) annual mean rainfall $\left(\mathrm{mm} \mathrm{year}^{-1}\right)$, (b) temperature $\left({ }^{\circ} \mathrm{C}\right)$, (c) soil depth $(\mathrm{cm})$ and $(\mathrm{d}) \mathrm{pH}$ as estimated by the GWR model. 


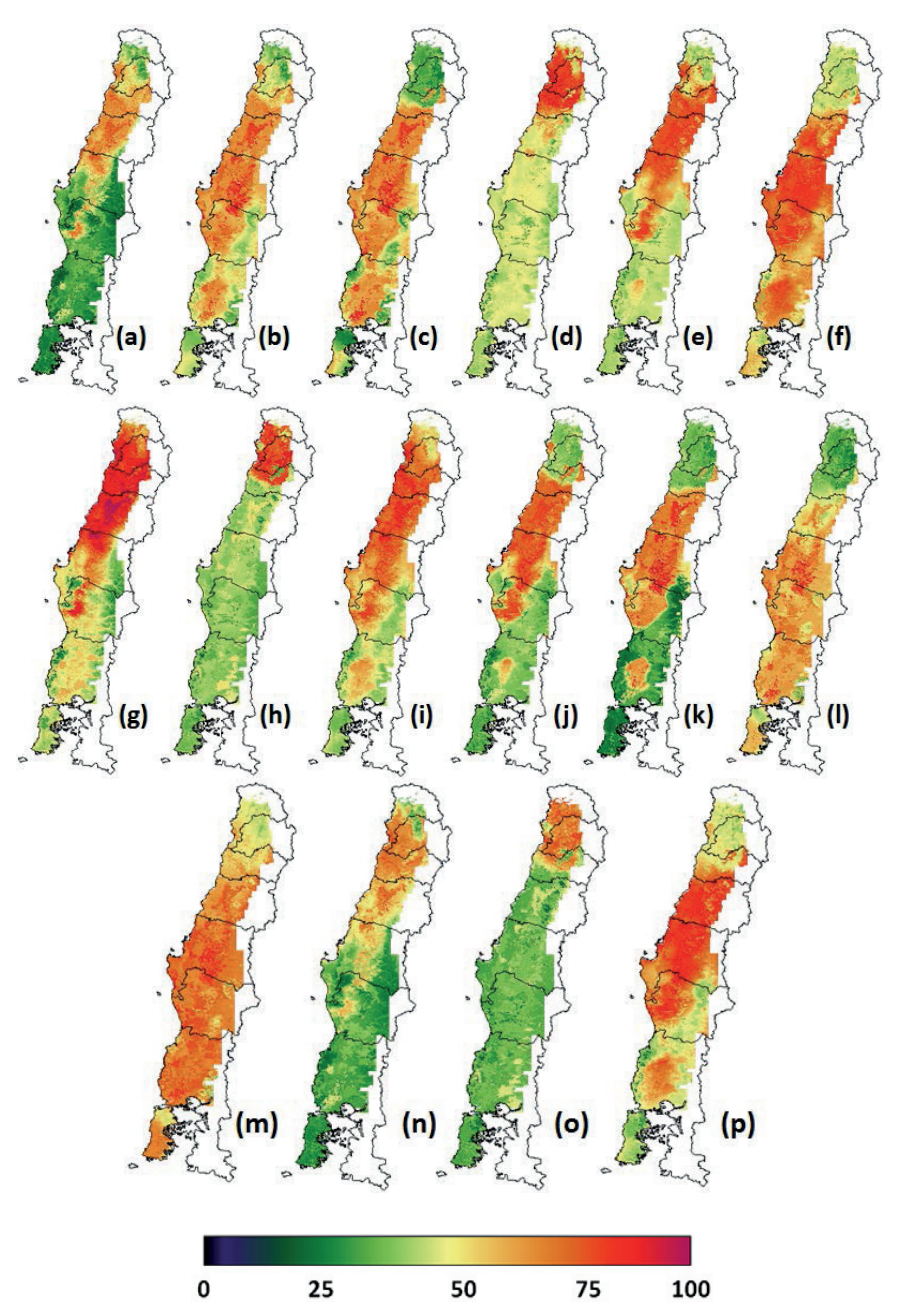

Figure 4. Land suitability maps for Acacia dealbata (a), A. mearnsii (b), A. melanoxylon (c), A. saligna (d), Arundo donax (e), Miscanthus x giganteus (f), Paulownia spp. (g), Salix viminalis (h), Eucalyptus camaldulensis (i), E. globulus (j), E. nitens (k), Populus deltoides (1), Populus spp. (m), Robinia pseudoacacia (n), Opuntia ficus-indica (o) and Panicum virgatum (p).

could potentially be established in rainfed areas. The ODEPA environmental homogeneous areas in each administrative region were used to estimate the suitability of the rainfed land for each species. Rainfed land accounts for approximately $47.435 \%$ of the area in Valparaíso, 24.17\% in Metropolitana, $30.482 \%$ in O'Higgins, $31.335 \%$ in Maule, $38.215 \%$ in Biobío, 25.303\% in Araucanía, 10.477\% in Los Lagos and $26.857 \%$ in Los Rios. Table 4 summarizes the mean agroclimatic suitability classes for the species by the administrative regions in the study area (Mendas and Delali, 2012; ParraQuijano et al., 2012).

\section{Discussion}

This study demonstrated that the habitat distribution patterns of bioenergy species in Central and Southern Chile can be effectively modeled using a small amount of occurrence data, environmental variables and the edapho-climatic requirements of species, which are available in databases such as EcoCrop. This study presents the spatial distributions of 16 bioenergy species based on their performance functions (Figure 1) and independent explanatory variables. Similar studies have used EcoCrop and DIVA-GIS to map the fundamental 
Table 4. Mean agroclimatic classes of the studied species in the coastal and interior rainfed areas of Valparaíso (V), Libertador Bernardo O’Higgins (VI), Maule (VII), Bío-Bío (VIII), Araucanía (IX), Los Lagos (X), Metropolitana (XIII) and Los Ríos (XIV). Regions are numbered as in Figure 1.

\begin{tabular}{lcccccccc}
\hline Species & V & VI & VII & VIII & IX & X & XIII & XIV \\
\hline Acacia dealbata & 3 & 4 & 4 & 3 & 2 & 2 & 3 & 2 \\
Acacia mearnsii & 3 & 4 & 4 & 4 & 4 & 4 & 3 & 3 \\
Acacia melanoxylon & 2 & 3 & 4 & 4 & 4 & 4 & 2 & 3 \\
Arundo donax & 4 & 4 & 5 & 4 & 4 & 3 & 3 & 3 \\
Acacia saligna & 5 & 4 & 3 & 3 & 3 & 3 & 5 & 3 \\
Eucalyptus camaldulensis & 4 & 4 & 5 & 4 & 4 & 4 & 4 & 3 \\
Eucalyptus globulus & 3 & 4 & 4 & 4 & 3 & 2 & 3 & 2 \\
Eucalyptus nitens & 2 & 3 & 4 & 4 & 4 & 2 & 2 & 2 \\
Miscanthus $x$ giganteus & 3 & 3 & 4 & 5 & 4 & 4 & 3 & 4 \\
Opuntia ficus-indica & 4 & 3 & 2 & 2 & 2 & 2 & 4 & 2 \\
Panicum virgatum & 3 & 4 & 5 & 5 & 4 & 3 & 3 & 3 \\
Paulownia tomentosa & 5 & 5 & 5 & 4 & 3 & 3 & 5 & 3 \\
Populus deltoides & 2 & 3 & 3 & 4 & 4 & 4 & 2 & 4 \\
Populus spp & 3 & 3 & 4 & 4 & 4 & 4 & 3 & 4 \\
Robinia pseudoacacia & 4 & 4 & 4 & 3 & 3 & 2 & 4 & 2 \\
Salix viminalis & 4 & 3 & 3 & 3 & 3 & 3 & 5 & 3 \\
\hline
\end{tabular}

ecological niches of species based on bioclimatic variables, but the applications have been limited due to the use of only two independent variables (Peterson, 2001; 2003; Pearson, 2007).

Based on the land suitability predicted by the EcoCrop method (Hijmans et al., 2005), the most suitable areas for A. dealbata were found to be the $\mathrm{O}^{\prime}$ Higgins and Maule regions, principally on Alfisol, Mollisol, Vertisol, Inceptisol and Andisol soils (CIREN, 2010). When using EcoCrop (Hijmans et al., 2005), we found that the areas with higher spatial suitability for $A$. mearnsii were the Maule, Bío-Bío and Araucanía regions on Alfisols, Mollisols, Vertisols, Inceptisols, Andisols, Histosols and Ultisols. These results agree with those from the INFOR (2014) database, which suggests that the south-central part of the country has the highest growth potential for this species. For A. melanoxylon, the regions with higher land suitability are Maule, Bío-Bío and Araucanía, but INFOR (2014) only identifies Bío-Bío as a potential region for this species. Similar to INFOR (2014), our results indicate that the most suitable regions for A. saligna are Valparaiso and Metropolitana on Alfisol, Entisol, Mollisol, Vertisol and other miscellaneous soils.

For both E. globulus and E. camaldulensis, EcoCrop (Hijmans et al., 2005) and INFOR (2014) predict suitable territory between the Valparaiso and Los Rios regions. As for E. nitens, its territorial suitability extends from the Maule to Los Rios regions.

Our results, as well as those from the INFOR (2014) database, predict that the most suitable territory for Populus spp is the Bío-Bío region on Ultisol, Andisol and Histosol soils. However, $P$. deltoides grows in a wide range of edaphoclimatic conditions, so the suitable area for its cultivation extends from $\mathrm{O}^{\prime}$ Higgins to Los Lagos.

The most suitable territory for $R$. pseudoacacia is located between Valparaíso and Maule but in patches with probabilities of occurrence between 50 and $62 \%$. In contrast, the most suitable territory for O. ficus-indica is found in the Valparaíso, Metropolitana and O’Higgins regions. 
A novel finding of this work is the high potential for rhizomatous perennial grasses, such as A. donax, Miscanthus $x$ giganteus and Panicum virgatum, which are suited to the wide edapho-climatic conditions of Central and Southern Chile. The most suitable area for these species is between the O'Higgins and Bio-Bio regions.

Differences in the predicted territorial suitability of the studied species between EcoCrop (Hijmans et al., 2005) and INFOR (2014) can be attributed to the variables used in both studies. In this work, we used precipitation, temperature, soil depth and $\mathrm{pH}$ as the explanatory variables, but in the INFOR (2014) studies, not all of the species were evaluated using the same variables. However, the results from both studies are not very different, and the predictions are quite similar in some cases.

The methodology presented here could be used to quantify the habitat distribution patterns of other plant species of ecological or economic interest. In particular, it has great potential for use in the study of threatened or endangered species as well as conservation and restoration efforts.

The results of this study are promising, especially considering the enormous energy potential of bio- mass in Chile (ProChile, 2009). Currently, there are 2 million hectares in the country available for reforestation (INFOR, 2011), and bioenergy crops will steadily accumulate biomass over time, positively affecting soils and preserving the country's natural resources (Rudnick et al., 2011).

Biomass is an abundant resource in Chile, but the country strongly depends on imported energy sources and is threatened by the permanent rise in international energy prices. For this reason and because of its commitment to reduce greenhouse gas emissions (Figueres, 2007), Chile must aim to increase its use of biomass as an energy source.

\section{Acknowledgements}

This work was part of the "Development of Bioenergy Crops" project, 08CTE02-06, by the Technological Consortium on Biofuels (Biocomsa), which is funded by CORFO-Innova. Dr. M.F. Alonso was partially funded by the "Programa de Inserción de Capital Humano Avanzado en la Academia" project, 79090011, CONICYT (Comisión Nacional de Investigación Científica y Tecnológica, Chile). We thank Drs. Alvaro Urzúa and Andreas Schmidt for their suggestions and invaluable expertise.

\section{Resumen}

L. Morales-Salinas, E. Acevedo, G. Castellaro, L.R. Osorio, J. Morales-Inostroza y M.F. Alonso. 2015. Un método simple para la estimación de la idoneidad territorial de especies bioenergéticas en Chile. Cien. Inv. Agr. 42(2): 227-242. En estos últimos 20 años diversas líneas de investigación en especies nativas y exóticas, cultivos herbáceos y plantaciones forestales se han orientado al desarrollo de aplicaciones energéticas domésticas, industriales y para el transporte. Como son un recurso importante, es estratégico contar con un método que permita identificar en el territorio nacional las áreas con aptitud para el cultivo de estas especies, con el objetivo de realizar una planificación territorial adecuada para el establecimiento de las plantaciones bioenergéticas. En este estudio se presenta un método simple para definir la idoneidad territorial de 16 especies con potencial energético (El Bassam, 2010) en el Centro y Sur de Chile, en base a sus requerimientos de suelo y clima. Se utilizó una adaptación del método EcoCrop implementado en el software DIVA-GIS para predecir la idoneidad de los cultivos en dicha zona geográfica. Los resultados muestran que el método propuesto representa una forma sencilla de estimar las zonas del territorio con idoneidad adecuada para establecer plantaciones bioenergéticas específicas, información que puede ser utilizada para la toma de 
decisiones en la planificación del territorio. La regresión espacialmente explicita y el kriging ordinario mostraron ser una herramienta satisfactoria de interpolación de los datos obtenidos de redes de estaciones climáticas para la generación de rejillas continuas de datos climáticos. La idoneidad territorial se presenta en un formato digital continuo expresado en términos probabilísticos a una escala 1:1,000,000.

Palabras clave: EcoCrop, especies bioenergéticas, idoneidad territorial, modelo de nicho ecológico.

\section{References}

Akaike, H. 1973. Information theory and an extension of the maximum likelihood principle. In: B.N. Petrov and F. Csaki (eds.). $2^{\text {nd }}$ International Symposium on Information Theory, Budapest, Akademiai Kiado. p. 267-281.

Almorox, J., M. Benito, and C. Hontoria. 2005. Estimation of monthly Angström-Prescott equation coefficients from measured daily data in Toledo, Spain. Renewable Energy 30: 931-936.

Alonso, M.F., C.R. Magni, and E. Acevedo. 2010. Cultivos lignocelulósicos con potencial bioenergético en Chile. Informe Técnico Biocomsa. Santiago, Chile. 189 pp.

Berry, W., and S. Feldman. 1985. Multiple Regression in practice, quantitative applications in the social science. SAGE. London, England. 93 pp.

Brunsdon, C., A.S. Fotheringham, and M.E. Charlton. 1996. Geographically weighted regression: A method for exploring spatial nonstationarity. Geographical Analysis 28: 281-298.

Burnham, K. P., and D. R. Anderson. 2002. Model selection and multimodel inference : A practical information-theoretic approach. Springer, New York. 488 pp.

Busby, J.R., 1991. Bioclim. A bioclimate analysis and prediction system. p. 64-68.In: Margules, C. R., and M.P. Austin (eds.). Nature conservation: cost effective biological surveys and data analysis. Canberra: CSIRO.

Cazanga, R., C. Leiva, and M. Retamal. 2010. Mapa de zonificación de aptitud productiva del territorio nacional de especies vegetales con potencial de producción de biocombustibles. ODEPA. Ministerio de Agricultura. Santiago, Chile. 235 pp.
CIREN-Centro de Investigaciones de Recursos Naturales. 1996. Estudio Agrológico Región Metropolitana. Chile. Public. 115. 464 pp.

CIREN-Centro de Investigaciones de Recursos Naturales. 1996. Estudio agrológico VI Región. Chile. Public. 114. 570 pp.

Centro de Investigaciones de Recursos Naturales (CIREN). 1997. Estudio Agrológico V Región. Chile. Public. 116. 392 pp.

CIREN-Centro de Investigaciones de Recursos Naturales. 1997. Estudio agrológico VII Región. Chile. Public. 117. 621 pp.

CIREN-Centro de Investigaciones de Recursos Naturales. 1999a. Estudio agrológico VIII Región. Chile. Public. 121. 583 pp.

CIREN-Centro de Investigaciones de Recursos Naturales. 1999b. Estudio agrológico IX Región. Chile. Public. 122. Chile. 326 pp.

CIREN-Centro de Investigaciones de Recursos Naturales. 2001. Estudio agrológico X Región. Chile. Public. 123. 403 pp.

CIREN-Centro de Investigaciones de Recursos Naturales. 2010. Determinación de la erosión actual y potencial de los suelos de Chile; Región del Maule, síntesis de resultados. 48 pp.

Chase, J.M., and M.A. Leibold. 2003. Ecological Niches. Linking Classical and Contemporary Approaches. The University of Chicago Press. Chicago. 212 pp.

Declerq, F.A.N. 1986. Interpolation methods for scattered sample data: Accuracy, spatial patterns, processing time. Cartography and Geographic Information Systems 23(3):128-144.

El Bassam, N. 2010. Handbook of Energy Crops. A Complete Reference to Species, Development and Applications. Earthscan, London. 516 pp. 
Fand, Babasaheb B., Mahesh Kumar and Ankush L. Kamble. 2014. Predicting the potential geographic distribution of cotton mealybug Phenacoccus solenopsis in India based on MAXENT ecological niche Model. Journal of Environmental Biology 35:973-982.

Farr, T., P. Rosen, E. Caro, R. Crippen, R. Duren, S. Hensley, M. Kobrick, M. Paller, E. Rodriguez, L. Roth, D. Seal, S. Shaffer, J. Shimada, J. Umland, M. Werner, M.Oskin, D. Burbank, and D. Alsdorf. 2007. The Shuttle Radar Topographic Mission. Reviews of Geophysics 45(2): RG2004.

Felicísimo, A.M. 1994. Modelos Digitales del Terreno: Introducción y aplicaciones en las ciencias ambientales. Available online at: http://www.etsimo. uniovi.es/ feli (Website accessed: October 2011).

Figueres, C. 2007. El Batik de Bali: Diseño del Régimen Climático post 2012. División de Desarrollo Sostenible y Asentamientos Humanos de la CEPAL. Santiago, Chile. 16 pp.

FAO-Food and Agriculture Organization. 1997. Zonificación Agroecológica. Guía General. Roma, $82 \mathrm{pp}$.

FAO-Food and Agriculture Organization. 2000. In: FAO (ed.). The Ecocrop Database. Rome, Italy.

FAO-Food and Agriculture Organization. 2008. El Estado Mundial de la Agricultura y la Alimentación. Biocombustibles: Perspectivas, Riesgos y Oportunidades. Roma, Italia. 162 pp.

Fotheringham, A., M. Charlton, and C. Brunsdon. 1997. Measuring spatial variations in relationship with geographically weigthed regression. In: M. Fischer, and A. Getis (eds.). Recent development in spatial analysis. Springer-Verlag. Berlin, Germany. p. 60-82.

Fotheringham, S., C.H. Brunsdaon, and M. Charlton. 2000. Quantitative Geography, Perspectives on spatial data analysis. SAGE publications. London, England. 272 pp.

Fotheringham, S., C.H. Brundson, and M. Charlton. 2002. Geographically Weighted Regression: The analysis of spatially varying relationships. WILEY, West Sussex. 269 pp.

Heuscher, S.A., Brandt, C.C., and Jardine, P.M. 2005. Using soil physical and chemical properties to estimate bulk density. SoilSci. Soc. Am. J. 69:51-56.
Gerencia Regional Agraria de La Libertad. 2009. Cultivo de tuna: Opuntia ficus-indica TrujilloPerú. 34 pp.

Geerts, S., D. Raes, M. Garcia, C. Del Castillo, and W. Buytaert. 2006. Agro-climatic suitability mapping for crop production in the Bolivian Altiplano: A case study for quinoa. Agricultural and Forest Meteorology 139: 399-412.

Grinnell, J. 1917. Field tests of theories concerning distributional control. American Naturalist 51: 115-128.

Grinnell, J. 1924. Geography and evolution. Ecology 5: 225-229.

Hebert, S., and P. Baurele. 1995. Aromo australiano (Acacia melanoxylon) en plantaciones mixtas. Revista Ciencias Forestales. Vol 10.

Hijmans, R.J., L. Guarino, C. Bussink, I. Barrantes, and E. Rojas. 2002. DIVA- GIS, Sistema de Información Geográfica para el Análisis de Datos de Biodiversidad. Available online at: http://cipotato.org/publications/pdf/003487.pdf (Website accessed: March 2015).

Hijmans, R.J., S.E. Cameron, J.L. Parra, P.J. Jones, and A. Jarvis. 2005. Very high resolution interpolated climate surfaces for global land areas. International Journal of climatology 25: 1965-1978.

INFOR-Instituto Forestal. 1999. Robinia pseudoacacia. Una alternativa multipropósito para la zona central. Documento divulgativo 15. Santiago, Chile. 12 pp.

INFOR-Instituto Forestal. 2000a. Descripción y antecedentes básicos sobre Acacia dealbata, Acacia melanoxylon y Acacia mearnsii. Revisión bibliográfica. Concepción, Chile. 47 pp.

INFOR-Instituto Forestal. 2000b. Eucalyptus camaldulensis en Chile. Silvicultura, manejo, productividad y rentabilidad. Santiago, Chile. 62 pp.

INFOR-Instituto Forestal. 2001b. Diversificación de alternativas de producción forestal y agroforestal para pequeños propietarios de secano. Monografía Acacia saligna, especie multipropósito como alternativa silvopastoral para zonas áridas de Chile. Santiago, Chile. 120 pp.

INFOR-Instituto Forestal. 2005. Establecimiento de plantaciones forestales; Eucalyptus sp. Santiago, Chile. 33 pp. 
INFOR-Instituto Forestal. 2011. Opciones dendroenergéticas eficiente como alternativa productiva para pequeños y medianos propietarios forestales. Available online at: http://www.infor.cl/es/ menu-proyectos/136/592-opciones-dendroenergeticas-eficiente.html (Website accessed: April 2013).

INFOR-Instituto Forestal. 2014. Estadísticas Forestales. Available online at: http://wef.infor.cl/ (Website accessed: July 2014).

Kaminski A., and J. Radosz. 2002. Topoklimaticzeskaja differencjacja territorii g. Tarnowskie Góry (Sileskajawozwyszennost, Polsza), Regional aspects of land use.p. 91-95.In: V.N. Andrejczuk, V.P. Korzyk (eds.). Chernivtsy-Sosnowiec.

Legates, D.R., and G.J. McCabe. 1999. Evaluating the use of goodness-of-fit measures in hydrologic and hydroclimatic model validation. Water Resources Research 35: 233-241.

Leibold, M.A. 1995. The niche concept revisited: Mechanistic models and community context. Ecology 76: 1371-1382.

Martinez-Cob, A. 1996. Multivariate geostatistical analysis of evapotranspiration and precipitation in mountainous terrain. Journal of Hidrology 174:19-35.

Mendas, A., and A. Delali. 2012. Integration of MultiCriteria Decision Analysis in GIS to develop land suitability for agriculture: Application to durum wheat cultivation in the region of Mleta in Algeria. Computers and Electronics in Agriculture 83: 117-126.

Miranda-Salas, M., and A.R. Condal. 2003. Importancia del análisis estadístico exploratorio en el proceso de interpolación espacial: Caso de estudio Reserva Forestal Valdivia. Bosque 24(2): 29-42.

Morales, L., F. Canessa, C. Mattar, R. Orrego, and F. Matus. 2006. Characterization and edaphic and climatic zonification in the region of Coquimbo, Chile. Revista Chilena Ciencia del Suelo y Nutrición Vegetal 6(3): 52-74.

Morales, L., F. Canessa, C. Mattar, and R. Orrego. 2007. Comparison of stochastic and regression geostatistics interpolation methods for detection of microclimatic areas. $5^{\text {th }}$ International Sym- posium on Spatial Data Quality, ISSDQ 2007, ITC Enschede, The Netherlands. Available online at:http://www.itc.nl/ISSDQ2007/proceedings/Session\% 202\%20 Spatial\%20Statistics/ Paper\%20Morales_et_al.pdf (Website accessed: May 2012).

Morales-Salinas, L., G. Castellaro-Galdames, J.C. Parra, J. Espinosa, F. Lang-Tasso, N. Ojeda-Ojeda, and H. Soto-Vera. 2009. Método de generación de cartografía climática usando regresiones con pesos geográficos. Simiente 79 (1-2): 74-82.

Morales, L., J. Parra, and J. Espinosa. 2010. Generation of continuous rasters of climatological variables using geographic weighted regression. Proceeding book $3^{\text {rd }}$ Recent Advances in Quantitative Remote Sensing. Universidad de Valencia. España.

Novoa, R., C. S. Villaseca, M. Del Canto, M. Rouanet, B. Sierra, and A. Del Pozo. 1989. Mapa Agroclimático de Chile, Instituto de Investigaciones Agropecuarias. Santiago, Chile. 221 pp.

Ojeda, N., R. Rebolledo, S. Calzadilla, H. Soto, and L. Morales. 2011. Methodological proposal for predictive and cartographic modeling of insect population: Semidalis kolbei case, the Araucanía Region, Chile. Ciencia e Investigación Agraria 38: 379-390.

Okolowicz, W. 1969. Derivatives of the term Climate and their gradation. GeographiaPolonica 16: 7785.

Parra-Quijano, M., J.M. Iriondo, and E. Torres. 2012. Ecogeographical land characterization maps as a tool for assessing plant adaptation and their implications in agrobiodiversity studies. Genet. Resour. Crop Evol. 59:205-217.

Parthasarthy, U., A. Johny, K. Jayarajan, and V. Parthasarathy. 2007. Site suitability for Turmeric production in India ó A GIS interpretation. Natural Product Radiance 6: 142-147.

Peterson, A.T. 2001. Predicting species' geographic distributions based on ecological niche modeling. Condor 103: 599-605.

Peterson, A.T. 2003. Predicting the geography of species' invasions via ecological niche modeling. The Quarterly Review of Biology 78: 419433. 
Pearson, R.G. 2007. Species distribution modeling for conservation educators and practitioners. Synthesis. American Museum of Natural History. Available online at: http://ncep.amnh.org (Website accessed: June 2011).

Phillips, S. J., R.P. Anderson, and R.E. Schapire. 2006. Maximum entropy modelling of species geographic distributions. Ecological Modeling 190:231-259.

Pliscoff, P., and T. Fuentes-Castillo. 2011. Modelación de la distribución de especies y ecosistemas en el tiempo y en el espacio: Una revisión de las nuevas herramientas y enfoques disponibles. Rev. Geogr. Norte Gd. 48: 61-79.

ProChile. 2009. Dirección de Promoción de Exportaciones. Análisis de las exportaciones chilenas. Available online at: http://www.prochile.gob. cl/.../analisis_exportaciones_chilenas_2009.pdf (Website accessed: April 24 2013).

R Development Core Team. 2009. R: A language and environment for statistical computing. R Foundation for Statistical Computing, Vienna, Austria. Available online at: http://www.R-project. org (Website accessed: January 2, 2012).

Ramirez-Villegas, J., A. Jarvisa, and P. Läderachd. 2013. Empirical approaches for assessing impacts of climate change on agriculture: The EcoCrop model and a case study with grain sorghum. Agricultural and Forest Meteorology 170: 67-78.

Rawls, W.J., D.L. Brakensiek, and K.E. Saxton. 1982 Estimation of soil water properties. Trans. Amer. Soc. of Agric. Engin. 25: 1316-1328.

Rudnick, H., C. Barría, R. Bellolio, and P. Karelovic. 2011. Energía de biomasa forestal, lecciones internacionales y su potencial en Chile. Pontificia Universidad Católica de Chile. Escuela de ingeniería. Departamento de Ingeniería Eléctrica. Santiago, Chile. 28 pp.

Saini, G.R. 1966. Organic matter as a measure of bulk density of soil. Nature 210: 1295-1296.

Santibañez, F., and J.M. Uribe. 1990. Atlas Agroclimático de Chile: Regiones V y Metropolitana, In: Facultad de Ciencias Agrarias y Forestales, Universidad de Chile (ed.). Santiago, Chile. 66 pp.
Santibañez, F., and J.M. Uribe. 1993a. Atlas Agroclimático de Chile: Regiones VI y VII, In: Facultad de Ciencias Agrarias y Forestales, Universidad de Chile (ed.). Santiago, Chile. 66 pp.

Santibañez, F., and J.M. Uribe. 1993b. Atlas Agroclimático de Chile: Regiones VIII y IX., In: Facultad de Ciencias Agrarias y Forestales, Universidad de Chile (ed.). Santiago, Chile. 66 p.

Saxton, K.E., W.J. Rawls, J.S. Romberger, and R.I. Papendick. 1986. Estimating Generalized Soilwater Characteristics from Texture. Soil Sci. Soc. Am. J. 50: 1031-1036. Sonder K., C.C. Okonkwo, and R. Asiedu. 2010. Predicted changes in suitability and agro climatic factors due to climate change for yam production in Nigeria. African Journal of Root and Tuber Crops 8: 51-59.

Sridhar1 V., A. Verghese, L.S. Vinesh, M. Jayashankar, and P.D.K. Jayanthi. 2014. CLIMEX simulated predictions of Oriental fruit fly, Bactrocera dorsalis (Hendel) (Diptera:Tephritidae) geographical distribution under climate change situations in India. Current Science 106: 1702-1710.

Stockwell, D., and D. Peters.1999. The GARP modelling system: Problems and solutions to automated spatial prediction. International Journal of Geographical Information Science 13: 143-158.

UACH. 2013. Evaluación del Mercado de la biomasa y su potencial. Ministerio de Energía. Santiago, Chile. 180 pp.

USDA-NRCS. 1999. Soil Taxonomy: A basic system of soil classification for making and interpreting soil surveys. Agriculture Handbook $\mathrm{N}^{\circ} 436$, 2nd edition. $871 \mathrm{pp}$.

Utpala, P., A.K, Johny, V.A. Parthasarathy, K. Jayaraja,n and M.S. Madan. 2006. Diversity of gingercultivation in India - a GIS study. Journal of Spices and Aromatic Crops 15: 93-99.

Vicente-Serrano, S., M. Saz-Sánchez, and J. Cuadrat. 2003. Comparative analysis of interpolation methods in the middle Ebro Valley (Spain); application to annual precipitation and temperature. Climate Research 24:161-180.

Yorukoglu, M., and A.N. Celik. 2006. A critical review on the estimation of daily global solar radiation from sunshine duration. Energy Conversion and Management 47 (15-16): 2441-2450. 